\title{
The Effect of Exercises Pursed Lips Breathing (PLB) Changes To Scale Of Breathlessness and Oxygen Saturation In COPD Patients At Hospital Dr. Soedarso Pontianak
}

\author{
Christianus Eko Purwanto Widoroni*, Florensius Andri, Eben Haezar Kristian \\ Nursing Academy of Dharma Insan, Pontianak, Indonesia \\ Corresponding author: christianus.eko@gmail.com
}

\begin{abstract}
Background: Chronic Obstructive Pulmonary Disease (COPD) is a narrowing of the air flow caused by inflammation in the airways resulting in the shortness of breath and reduced oxygen levels in the blood thereby affecting patients' quality of life.

Purpose: The purpose of this study was to determine the effect of exercise on the PLB to Scale of Breathlessness and oxygen saturation $(\mathrm{SaO} 2)$ in COPD patients.

Methods: The research method utilized quasi experimental design with randomized pretestposttest control group. Sample of 68 respondents (60 respondents PLB group, and 8 respondents control group) was recruited through total sampling technique.

Result: Independent t-test showed difference of decreasing Scale of Breathlessness $(\mathrm{p}=0.018) \&$ increasing of $\mathrm{SaO} 2(\mathrm{p}=0.023)$ between PLB \& control group. The results of Multiple linear regression test showed an effect of PLB on a Scale of Breathlessness $(\mathrm{p}=0.030)$ and $\mathrm{SaO} 2(\mathrm{p}=0.002)$.
\end{abstract}

Conclusion: It can be concluded that the PLB exercises influenced changes in the value Scale of Breathlessness and $\mathrm{SaO} 2$.

Keywords: COPD, Oxygen Saturation, Pursed Lip Breathing Exercises, Scale Of Breathlessness. 
Journal Of Nursing Practice

http://thejnp.org

ISSN: 2614-3488 (print); 2614-3496 (online)

Vol.5 No.1. October 2021. Page.176-181

\section{BACKGROUND}

Chronic Obstructive Pulmonary Disease (COPD) is a progressive and irreversible respiratory tract disorder in the form of obstruction or narrowing of the respiratory tract caused by inflammation or inflammation resulting from the inhalation of harmful gases or particles such as cigarette smoke which will eventually cause shortness of breath. COPD can cause several other diseases associated with airway obstruction such as chronic bronchitis and emphysema. Patients with COPD have symptoms including dyspnea, chronic cough, and chronic sputum production (Lewis, Dirksen, Heitkemper, Bucher, \& Camera, 2011).

COPD and related respiratory diseases are estimated to affect 24 million adults and are the third leading cause of death in the United States. COPD affects more than 5\% of the adult population in the United States. It is estimated that 27 million adults have COPD, 14 million have been diagnosed with COPD and more than 12 million adults have not been diagnosed with COPD (Hinkle \& Cheever, 2014). The incidence of COPD in Indonesia in 2013 was $4.2 \%$ in men and $3.3 \%$ in women. West Kalimantan province has a COPD incidence rate of $3.5 \%$ and Maluku province has a COPD incidence rate of around $4.3 \%$ (Riskesdas, 2013)

COPD will have a major impact on clients starting from dyspnea which has become a common symptom in clients with COPD. Usually dyspnea is progressive, draining, and can occur every day. Gradually, dyspnea can interfere with daily activities, for example, patients cannot walk as fast as their partners or friends, this will affect behavior changes. In addition, dyspnea can also occur at rest. Patients with severe COPD may also experience chronic anemia, anxiety, depression, and an increased incidence of cardiovascular disease (Lewis, et al, 2011).

Research conducted by (Monteagudo, et al., 2013) states that COPD with symptoms of shortness of breath are chronic, progressive, irreversible and have an impact on limited activity which will ultimately affect the quality of health. This is supported by the results of a study conducted by (Raherison, Leblond, Prudhomme, \& Taille, 2014) on 430 COPD patients, showing that COPD affects a decrease in quality of life in $50.6 \%$ of respondents with a $\mathrm{p}$ value $<0.02$.

Compliance with oxygenation is a serious concern for COPD patients, especially those with dyspnea or severe shortness of breath. Oxygenation is a basic human need that plays an important role in the continuity of the body's cell metabolism processes, maintaining life and the activities of various organs. The presence of oxygen is one of the gas components and a vital element in the metabolic processes and functions of all body cells (Andarmoyo, 2012).

One of the pulmonary rehabilitation measures in COPD clients is breathing exercises. All clients with COPD benefit from a breathing exercise program, namely the client shows improvement in the form of tolerance exercises and decreases dyspnea and fatigue. Exercise does not improve lung function more effectively, but rather has an impact on strengthening the respiratory muscles. Breathing exercises include Diaphragmatic Breathing and Pursed-lips Breathing (Black \& Hawks, 2009).

The benefits of this rehabilitation include increased exercise capacity, reduced perceived intensity of shortness of breath, improved health-related quality of life, reduced number of hospitalizations and days in hospital, and reduced anxiety and depression associated with COPD. This pulmonary rehabilitation can be performed in COPD patients with grades II to IV within an effective time span of 6 weeks (Hinkle \& Cheever, 2014).

Breathing techniques, such as pursed-lips breathing, can help control dyspnea. This exercise has the effect of reducing the amount of residual air in the lungs, the client also 


\section{Journal Of Nursing Practice}

http://thejnp.org

ISSN: 2614-3488 (print); 2614-3496 (online)

Vol.5 No.1. October 2021. Page.176-181

gains confidence in controlling and managing dyspnea. This breathing exercise technique should be taught when the patient is free from dyspnea (Ignatavicius \& Workman, 2010).

Based on the above background, by looking at the tendency of COPD patients to experience shortness of breath which results in a decrease in oxygen saturation values, the authors are interested in conducting a study entitled: " The Effect Of Exercises Pursed Lips Breathing (PLB) Changes To Scale Of Breathlessness And Oxygen Saturation In COPD Patients at Hospital Dr. Soedarso Pontianak".

\section{METHODS}

This study is a quasi-experimental design study with a randomized pretest-posttest control group design. The population in this study were 68 respondents. This research was conducted in Hospital Dr. Soedarso Pontianak in April 2020. In this study, the sampling technique used was exhaustive sampling or total sampling.

The inclusion criteria of respondents in this study were patients suffering from COPD based on the MRCs dyspnea scale assessment on a scale of 2 to 4, oxygen saturation $<95 \%$.

The instrument in this study is a calibrated oximetry used to measure oxygen saturation and the Medical Research Council Dyspnea Scale is one of the scales to assess the degree of shortness of breath during activities. This dyspnea scale consists of a range of 0 (zero) to 4 (four) based on activity level, where a scale of 0 (zero) is no shortness of breath except with strenuous activity, a scale of 1 (one) is that shortness of breath begins when walking fast or climbing stairs. level, a scale of 2 (two) is walking slower because of feeling short of breath, a scale of 3 (three) is shortness of breath when walking $100 \mathrm{~m}$ or after a few minutes, a scale of 4 (four) is shortness of breath when bathing or dressing (GOLD, 2015).

In this study, data analysis was carried out using the SPSS 22 statistical application. The analysis used included independent t-test analysis. This analysis was used to see the comparison value between the intervention group and the control group. And multivariate analysis of multiple linear regression this analysis is used to see the effect of the independent variable on the dependent variable.

\section{RESULTS}

\section{Univariate Analysis}

Table 1. Distribution of Respondents by Age in Hospital Dr. Soedarso Pontianak

\begin{tabular}{lcccc}
\hline \multicolumn{1}{c}{ Age } & Max & Min & Mean & Total \\
\hline PLB & 86 & 25 & 59 & 68 \\
Control & 66 & 24 & 51 & \\
\hline
\end{tabular}

Source: 2016 primary data

Table 2. Distribution of Respondents by Gender in Hospital Dr. Soedarso Pontianak

\begin{tabular}{lcccccc}
\hline \multirow{2}{*}{ Gender } & \multicolumn{2}{c}{ PLB } & \multicolumn{2}{c}{ Control } & \multicolumn{2}{c}{ Total } \\
\cline { 2 - 7 } & $\mathrm{n}$ & $\%$ & $\mathrm{n}$ & $\%$ & $\mathrm{n}$ & $\%$ \\
\hline Man & 42 & 70 & 4 & 50 & 46 & 67,6 \\
Women & 18 & 30 & 4 & 50 & 22 & 32,4 \\
\hline \multicolumn{1}{c}{ Total } & 60 & 100 & 8 & 100 & 68 & 100 \\
\hline
\end{tabular}

Source: 2016 primary data 


\section{Journal Of Nursing Practice}

Table 3. Distribution of Respondents Based on History of Exposure to Pollutants at Hospital Dr. Soedarso Pontianak

\begin{tabular}{lcccccc}
\hline History of Exposure & \multicolumn{2}{c}{ PLB } & \multicolumn{2}{c}{ Control } & \multicolumn{2}{c}{ Total } \\
\cline { 2 - 7 } to Pollutants & $\mathrm{n}$ & $\%$ & $\mathrm{n}$ & $\%$ & $\mathrm{n}$ & $\%$ \\
\hline $\begin{array}{l}\text { Frequent exposure to } \\
\text { pollutants }\end{array}$ & 41 & 68,3 & 5 & 62,5 & 46 & 67,6 \\
$\begin{array}{l}\text { Not exposed to } \\
\text { pollutants }\end{array}$ & 19 & 31,7 & 3 & 37,5 & 22 & 32,4 \\
\hline Total & 60 & 100 & 8 & 100 & 68 & 100 \\
\hline & & Source: 2016 primary data &
\end{tabular}

Table 4. Average scores before and after intervention for the Respondent's Shortness of Breath Scale by Group at Hospital Dr. Soedarso Pontianak

\begin{tabular}{ccccc}
\hline \multirow{2}{*}{ Group } & \multirow{2}{*}{$\mathrm{n}$} & \multicolumn{2}{c}{ Mean } & \multirow{2}{*}{ Difference } \\
\cline { 3 - 4 } & & Pre & Post & \\
\hline PLB & 60 & 3,13 & 1,60 & 1,53 \\
Control & 8 & 3.38 & 2,13 & 1,25 \\
\hline \multicolumn{4}{l}{ Source: 2016 primary data }
\end{tabular}

Table 5. Average scores before and after intervention for Oxygen Saturation of Respondents by Group at Hospital Dr. Soedarso Pontianak

\begin{tabular}{ccccc}
\hline \multirow{2}{*}{ Group } & \multirow{2}{*}{$\mathrm{n}$} & \multicolumn{2}{c}{ Mean } & \multirow{2}{*}{ Difference } \\
\cline { 3 - 4 } & & Pre & Post & \\
\hline PLB & 60 & 87,68 & 95,50 & 7,82 \\
Control & 8 & 88,75 & 93,63 & 4,88 \\
\hline
\end{tabular}

Source: 2016 primary data

\section{Independent Test}

Table 6. Differences in the Scale of Breathlessness and oxygen saturation between the intervention group Pursed Lip Breathing and the control group at Hospital Dr. Soedarso

\begin{tabular}{lccc}
\hline \multicolumn{1}{c}{ Variabel } & PLB & Control group & pvalue \\
\hline $\begin{array}{l}\text { Scale of } \\
\begin{array}{l}\text { Breathlessness } \\
\text { oxygen saturation }\end{array}\end{array}$ & 1,60 & 2,13 & 0,018 \\
\hline
\end{tabular}

Source: 2016 primary data

\section{Multivariate Analysis}

Table 7. The effect of Pursed Lip Breathing exercises on changes in Scale of Breathlessness and oxygen saturation values in Hospital Dr. Soedarso Pontianak

\begin{tabular}{ccc}
\multirow{2}{*}{ Variabel } & \multicolumn{2}{c}{ Sig. } \\
\cline { 2 - 3 } PLB & Scale of Breathlessness & oxygen saturation \\
\hline \multicolumn{2}{c}{$p 0,030$} & $p 0,002$ \\
\hline
\end{tabular}


Journal Of Nursing Practice

http://thejnp.org

ISSN: 2614-3488 (print); 2614-3496 (online)

Vol.5 No.1. October 2021. Page.176-181

\section{DISCUSSION}

\section{Comparison between the Pursed Lip Breathing Exercise intervention group and the control group}

In Table 6, it can be seen that the results of the independent t-test analysis showed that the shortness of breath scale value $p$ value was 0.018 , and oxygen saturation $p$ value was 0.023 , it can be concluded that there was a significant difference in the value of the shortness of breath scale and oxygen saturation between the Pursed Lip Breathing intervention group. and control group. So it can be concluded that the intervention of Pursed Lip Breathing exercise has a better effect on decreasing the shortness of breath scale and increasing oxygen saturation when compared to the control group.

Pursed Lip Breathing is a breathing exercise technique that aims to prolong expiration and increase air pressure so as to delay airway compression and reduce trapped air. Pursed Lip Breathing breathing exercises can also significantly reduce dyspnea (Lewis, et at., 2011)

The results of this study are supported by the results of research conducted by (Bakti, Rosella, \& Sugiono, 2015) that the Pursed Lip Breathing exercise in the intervention group gave a more significant effect $(p=0.002)$ than the control group $(p=0.014)$ in reducing the level of hard to breathe.

\section{The effect of Pursed Lip Breathing exercise on changes in the Scale of Breathlessness and oxygen saturation}

Based on Table 7 above, the p-value of the Scale of Breathlessness is $0.030<0.05$ and the p-value of oxygen saturation is $0.002<0.05$ so that statistically Pursed Lip Breathing exercise significantly affects changes in the shortness of breath scale and oxygen saturation. So it can be concluded that Pursed Lip Breathing exercise can reduce the scale of shortness of breath and increase oxygen saturation in COPD patients.

Pursed Lip Breathing is a breathing exercise that emphasizes the expiration process with the aim of facilitating the process of expelling air trapped in the airways. Through this technique, the air that comes out will be blocked by both lips, and will cause the pressure in the oral cavity to be more positive this reduces the resistance of the airways to the release of air and consequently lowers the residual volume and facilitates the entry of air during the inspiration process and affects the increase in gas exchange. and ventilation. This will result in an increase in oxygen saturation $(\mathrm{SaO} 2)$ and partial pressure of oxygen in the blood $(\mathrm{PaO} 2)$, and a decrease in the partial pressure of carbon dioxide in the blood $(\mathrm{PaCO} 2)$ as well as an increase in tidal volume, greater recruitment of expiratory muscles and a decrease in respiratory rate (RR). (Hinkle \& Cheever, 2014).

Research conducted by (Visser, Ramlal, Dekhuijzen, \& Heijdra, 2011) showed that Pursed Lip Breathing exercise significantly increased respiratory capacity $(p=0.006)$, oxygen saturation increased by $1 \%(\mathrm{p}=0.005)$, carbon dioxide and frequency respiration decreased significantly $(\mathrm{p}<0.0001$, for both)

Research conducted by (Izadi-avanji \& Adib-Hajbaghery, 2011) said that Pursed Lip Breathing exercise can significantly reduce respiratory rate $(\mathrm{p}<0.001)$, significantly increase oxygen saturation value $(\mathrm{p}<0.05)$, decrease PaCO2 $(\mathrm{p}<0.05)$, as well as an increase in daily activities $(\mathrm{p}<0.05)$

\section{CONCLUSION}

From the results of this study, it was found that the most frequent decrease in the shortness of breath scale was found in the pursed lip breathing exercise group from an average of 3.13 before the intervention to an average of 1.60 after the intervention with a 


\section{Journal Of Nursing Practice}

http://thejnp.org

difference of 1.53 changes. In the average oxygen saturation, the difference in the increase in oxygen saturation values was mostly found in the Pursed Lip Breathing exercise group from an average of 87.68 before the intervention to an average of 95.50 after the intervention with a difference of 7.82 changes.

Based on the results of multiple linear regression analysis for the effect of Pursed Lip Breathing exercise on changes in the scale of breathlessness and oxygen saturation, the $\mathrm{p}$-value of the shortness of breath scale is $0.030<0.05$ and the $\mathrm{p}$-value of oxygen saturation is $0.002<0.05$ so it can be concluded that PLB exercise has a significant effect on changes in scale of breathlessness and oxygen saturation.

\section{ACKNOWLEDGMENTS}

Thank you to the nurse from Dr. Soedarso General Hospital

\section{REFERENCES}

Andarmoyo, S. (2012). Kebutuhan Dasar Manusia (Oksigenasi). Yogyakarta: Graha Ilmu.

Bakti, A. K., Rosella, D., \& Sugiono. (2015). Pengaruh Pursed Lip Breathing Exercise Terhadap Penurunan Tingkat Sesak Napas Pada Penyakit Paru Obstruksi Kronik (PPOK) Di Balai Besar Kesehatan Paru Masyarakat BBKPM Surakarta. Universitas Muhammadiyah Surakarta.

Black, J. M., \& Hawks, J. H. (2009). Medical Surgical Nursing; Clinical Management for Positive Outcomes. Singapore: SAUNDERS; Elsevier.

GOLD. (2015). Pocket Guide To COPD Diagnosis, Management, and Prevention.

Hinkle, J. L., \& Cheever, K. H. (2014). Brunner \& Suddarth's Textbook of Medical Surgical Nursing. Philadelphia: Lippincott Williams \& Wilkins.

Ignatavicius, D. D., \& Workman, M. (2010). Medical Surgical Nursing ;Patient Centered Collaborative Care. St. Louis, Missouri: Saunders; Elsevier.

Izadi-avanji, F. S., \& Adib-Hajbaghery, M. (2011). Effects of Pursed Lip Breathing on Ventilation and Activities of Daily Living in Patients with COPD. Webmed Central.

Lewis, S. L., Dirksen, S. R., Heitkemper, M. M., Bucher, L., \& Camera, I. M. (2011). Medical Surgical Nursing; Assessment and Management of Clinical Problems. St. Louis, Missouri: Elsevier; Mosby.

Monteagudo, M., Rodriguez-Blanco, T., Liagostera, M., Valero, C., Bayona, V., Ferrer, M., \& Miravitlles, M. (2013). Factors associated with changes in quality of life of COPD patients: a prospective study in primary care. Respir Med.

Raherison, C., Leblond, I. T., Prudhomme, A., \& Taille, C. (2014). Clinical characteristics and quality of life in women with COPD: An observational study . BMC Women's Health.

Riskesdas. (2013). Riset Kesehatan Dasar. Kementerian Kesehatan RI.

Visser, F. J., Ramlal, S., Dekhuijzen, P. R., \& Heijdra, Y. F. (2011). Pursed-lip breathing improves inspiratory capacity in COPD . Respiration. 